\title{
Antiphospholipid syndrome: five year follow up
}

\author{
Ronald A Asherson, Elaine Baguley, Chobie Pal, Graham R V Hughes
}

\begin{abstract}
Nineteen patients out of 250 subjects with antiphospholipid antibodies, who had initially presented to the lupus clinic at St Thomas's Hospital, London five or more years ago with a history of venous/arterial occlusions, were entered into the study. The patients were divided into two main groups: I those who remained well without any further thromboembolic complications $(n=10)$; II those who developed recurrent thrombotic events in the five year period $(n=9)$.
\end{abstract}

The patients were followed up to determine the relation between the level or the isotype of the anticardiolipin antibodies, or both, to the recurrent thromboembolic events, and the effect of a variety of treatments (corticosteroids, immunosuppression, anticoagulation) in the prevention of further vascular occlusions. Lupus activity over the five year period varied considerably between the two groups-those in group I tending to be relatively inactive compared with those in group II. For some patients in group II thromboembolic events seemed to occur at the time of lupus activity.

Antiphospholipid antibodies remained positive in all patients, the levels remaining fairly constant. Levels fell in only one patient in group I and in two in group II. Patients in group II had more systemic lupus erythematosus related disease than those in group I; most were receiving concomitant steroid and immunosuppressive therapy, but this did not seem to protect against the development of further occlusions. All patients were given anticoagulation treatment (warfarin/heparin) or salicylates (low dose aspirin $75 \mathrm{mg}$ daily), or both. Patients with deep vein thromboses developed more complications during anticoagulation therapy than those with cerebrovascular symptoms. Problems in anticoagulation control and recurrent thromboses consequent on warfarin withdrawal despite the administration of subcutaneous heparin were responsible for complications in most patients in group II.

Unit, The Rayne

Institute, St Thomas's

Hospital, London

SE1 7EH

R A Asherson

E Baguley

C $\mathrm{Pal}$

G R V Hughes

Correspondence to:

Dr R A Asherson,

Division of Rheumatology and

Division of Rheumatology and

St Lukes/Roosevelt Hospital

Center, Columbia University,

Center, Columbia University,
New York, NY 10019, USA.

Accepted for publication

18 March 1991 consequence of thrombosis of veins as well as arteries $^{12}$ : recurrent fetal loss, ${ }^{3}$ haematological (thrombocytopenia, Coombs' positivity/haemolytic anaemia), dermatological (livedo reticularis, skin nodules/necrosis), and neurological (chorea, transverse myelitis, dementia) complications. ${ }^{4}$ These complications in about $50 \%$ of patients occur in association with systemic lupus erythematosus (SLE) or 'lupuslike' disease, a variant of SLE, with patients essentially showing less than four of the revised criteria for the classification of SLE as laid down by the American Rheumatism Association in 1982.5

Criteria for an 'antiphospholipid syndrome' were proposed in 1987 by Harris et al, ${ }^{6}$ comprising essentially the combination of vascular occlusions and thrombocytopenia accompanied by persisting increases of anticardiolipin antibodies or presence of the lupus anticoagulant, or both. The antiphospholipid syndrome in $50 \%$ of patients is seen without any clinical or serological evidence of SLE-the recently defined 'primary' antiphospholipid syndrome. ${ }^{7-9}$

It is still unclear whether these antibodies alone are the direct cause of thrombotic events by a number of differing mechanisms, or whether they constitute 'markers' present in most patients with clotting problems and lupustype illness.

This study aimed at determining whether there was any quantitative change in antibody levels preceding the recurring thrombotic events in patients originally presenting with an antiphospholipid syndrome and what, if any, other 'trigger' factors might contribute to the occurrence of such events in these susceptible patients over a five year period.

Patients and methods

All patients were defined as having an 'antiphospholipid syndrome' according to the criteria proposed in $1987 .^{6}$ Patients with recurrent fetal losses were excluded as they will form part of a separate study. All patients were thrombocytopenic either initially or at some point during the five years. Fluctuations in platelet counts were not considered in the study. Anticardiolipin antibody estimations were performed at three to six monthly intervals at routine follow up visits. The anticardiolipin antibody levels were defined as low (for IgG and IgM anticardiolipin antibody) ( $<20$ units); moderate (20-80 units); and high ( $>80$ units).

The lupus anticoagulant was not routinely measured at follow up as most patients were receiving anticoagulant treatment. Estimations of protein $C$, protein $S$, and antithrombin III concentrations were also not measured for similar reasons. Blood of patients with a history 
of deep vein thromboses unrelated to high risk situations, such as oral contraceptive use or pregnancy, was anticoagulated with warfarin (Coumadin). Long term anticoagulation was continued in the presence of positive anticardiolipin antibody tests. Subcutaneous/intravenous heparin was used when warfarin was withdrawn for particular reasons-for example, before biopsies or in preparation for surgery.

In patients with cerebrovascular accidents alone the presence of valve abnormalities suggested the possibility of embolic events rather than in situ thrombosis, and in most of these patients aspirin was used initially, with warfarin added if recurrent cerebrovascular or other events supervened.

Lupus disease activity was assessed and further treatments were introduced when required. These therapies were not used solely for the attempted treatment of thrombosis.

For analytical purposes the patients were divided into two groups: I those without further thromboembolic complications $(n=10)$; II those who developed recurrent thrombotic events $(n=9)$.

All patients had complete histories taken, including social, medical, and family details, at the start of the study. The family history included specific questions about the presence of a connective tissue disease or coagulopathy in family members. All patients had routine blood counts as well as biochemical and immunological evaluations during the study period. Anticardiolipin antibodies were determined by an enzyme linked immunosorbent assay (ELISA), as modified by Gharavi et al. ${ }^{10}$ The lupus anticoagulant was evaluated by the method of Exner. ${ }^{11}$

\section{Results}

GROUP I (table 1)

Five patients were diagnosed as having SLE initially. Four had 'lupus-like' disease at the onset, with evolution to SLE after five years in one. One patient was defined as having a 'primary' antiphospholipid syndrome. Four patients had a cerebrovascular accident only, which in one had developed during oral contraceptive use. A fifth patient had a history of two deep vein thromboses occurring before the cerebrovascular accident-one in the postpartum period and one during oral contraceptive use. Four patients had deep vein thromboses, and in one this was accompanied by a retinal artery thrombosis. One patient had an arterial occlusion of the leg.

Two of the five patients with cerebrovascular accidents were treated with aspirin as the sole anticoagulant. In one the aspirin was accompanied by prednisolone and in the other by prednisolone and azathioprine. The third patient with a cerebrovascular accident was treated with warfarin alone. The fourth patient with a cerebrovascular accident, which followed recurrent deep vein thromboses, was also treated with aspirin accompanied by prednisolone. The fifth patient who had developed a cerebrovascular accident while taking dipyridamole was then changed to warfarin without the addition of prednisolone or azathioprine and has remained well. Therefore, of the five patients with cerebrovascular accidents, none of whom developed further thrombotic complications, three had been treated with aspirin alone as the anticoagulant and two had been treated with warfarin only.

Of the five patients with deep vein thromboses, two had received warfarin alone, one aspirin alone, and two warfarin plus aspirin. Concomitant low dose prednisolone had been given to four of these five patients.

The patient with arterial occlusion of the leg despite persistently high levels of IgM anticardiolipin antibodies throughout the total five year period has remained well with long term warfarin treatment and has had no further occlusions. This patient is also a heavy smoker, who continued to smoke despite medical advice to the contrary, as well as having hypercholesterolaemia.

Of the 10 patients in group $I$, nine were positive for anticardiolipin antibodies and one was negative. All nine patients were positive for IgG anticardiolipin antibodies throughout the period, one patient converting from a high to a moderate positive value within the five year period and also from a low to a negative IgM anticardiolipin antibody level in the same period. Two patients, one with a cerebrovascular

Table 1 Antiphospholipid syndrome: group $I^{*}$

\begin{tabular}{|c|c|c|c|c|c|c|c|c|c|}
\hline \multirow{2}{*}{$\begin{array}{l}\text { Case } \\
\text { No }\end{array}$} & \multicolumn{2}{|l|}{ Diagnosis } & \multirow{2}{*}{$\begin{array}{l}\text { Initial APS } \\
\text { associated } \\
\text { manifestations }\end{array}$} & \multirow{2}{*}{$\begin{array}{l}\text { Further } \\
\text { complications }\end{array}$} & \multicolumn{2}{|l|}{ Treatment } & \multicolumn{3}{|c|}{ Antiphospholipid antibodies } \\
\hline & Onset & At 5 years & & & Anticoagulation & $\begin{array}{l}\text { Prednisolonel } \\
\text { immunosuppression }\end{array}$ & $\begin{array}{l}I g G \\
a C L t\end{array}$ & $\begin{array}{l}I g M \\
a C L\end{array}$ & LAf \\
\hline $\begin{array}{l}1 \\
2\end{array}$ & $\begin{array}{l}\text { SLE† } \\
\text { SLE }\end{array}$ & $\begin{array}{l}\text { SLE } \\
\text { SLE }\end{array}$ & $\begin{array}{l}\text { CVAt during OCt use } \\
\text { CVA }\end{array}$ & $\begin{array}{l}\text { Nil } \\
\text { Nil }\end{array}$ & $\begin{array}{l}\text { Aspirin } \\
\text { Aspirin }\end{array}$ & $\begin{array}{l}\text { Prednisolone } \\
\text { Prednisolone+ } \\
\text { azathioprine }\end{array}$ & $\begin{array}{l}\mathrm{Neg} \\
\mathrm{Lf}\end{array}$ & $\underset{M \rightarrow L}{\mathrm{Neg}}$ & $\begin{array}{l}+ \\
+\end{array}$ \\
\hline $\begin{array}{l}3 \\
4\end{array}$ & $\begin{array}{l}\text { LLD }+ \\
1^{\circ} \text { APS } †\end{array}$ & $\begin{array}{l}\text { SLE } \\
1^{\circ} \text { APS }\end{array}$ & $\begin{array}{l}\text { DVT } \dagger \\
\text { CVA while taking } \\
\text { dipyridamole }\end{array}$ & $\begin{array}{l}\text { Nil } \\
\text { Nil }\end{array}$ & $\begin{array}{l}\text { Warfarin } \\
\text { Warfarin }\end{array}$ & $\begin{array}{l}\text { Prednisolone } \\
\text { Nil }\end{array}$ & $\underset{M}{M S}$ & - & $\stackrel{+}{\text { ND }}$ \\
\hline $\begin{array}{r}5 \\
6 \\
7 \\
8 \\
9 \\
10\end{array}$ & $\begin{array}{l}\text { LLD } \\
\text { SLE } \\
\text { LLD } \\
\text { SLE } \\
\text { SLE } \\
\text { LLD }\end{array}$ & $\begin{array}{l}\text { LLD } \\
\text { SLE } \\
\text { LLD } \\
\text { SLE } \\
\text { SLE } \\
\text { LLD }\end{array}$ & $\begin{array}{l}\text { CVA } \\
\text { DVT } \\
\text { DVT } \times 2, \ddagger \text { CVA } \\
\text { DVT } \\
\text { DVT, retinal artery thrombosis } \\
\text { Arterial occlusion (leg), } \\
\text { (arteriosclerosis, smoker }++ \text { ) }\end{array}$ & $\begin{array}{l}\text { Nil } \\
\text { Nil } \\
\text { Nil } \\
\text { Nil } \\
\text { Nil } \\
\text { Nil }\end{array}$ & $\begin{array}{l}\text { Warfarin } \\
\text { Warfarin } \\
\text { Aspirin } \\
\text { Warfarin + aspirin } \\
\text { Warfarin + aspirin } \\
\text { Warfarin }\end{array}$ & $\begin{array}{l}\text { Nil } \\
\text { Prednisolone } \\
\text { Prednisolone } \\
\text { Prednisolone } \\
\text { Nil } \\
\text { Nil }\end{array}$ & $\begin{array}{l}\underset{H}{H} \rightarrow M \\
M \\
\mathbf{L} \\
\mathbf{M} \\
\mathbf{H}\end{array}$ & $\begin{array}{l}\bar{L} \rightarrow \mathrm{Neg} \\
= \\
= \\
-\end{array}$ & $\begin{array}{l}+ \\
+ \\
+ \\
\text { ND } \\
+ \\
+\end{array}$ \\
\hline
\end{tabular}

* Patients without further thromboembolic complications during the five year follow up.

†SLE = systemic lupus erythematosus; LLD=lupus-like disease; $1^{\circ} \mathrm{APS}=$ primary antiphospholipid syndrome; CVA=cerebrovascular accident, $\mathrm{OC}=$ ora contraceptive; $\mathrm{DVT}=$ deep vein thromboses; $\mathrm{aCL}=$ anticardiolipin antibody; $\mathrm{LA}=$ lupus anticoagulant.

fOne episode post partum, once during oral contraceptive use.

$\$ \mathrm{~L}=$ low ( $<20$ units); $M=$ moderate (20-80 units), $\mathrm{H}=$ high ( $>80$ units) 
accident and one with deep vein thromboses, had low IgG anticardiolipin antibodies; in the first patient this was accompanied by a moderate increase of the IgM anticardiolipin antibodies, which fell to a low level at the end of the five year period. The lupus anticoagulant test was positive in all eight patients in whom it was performed.

\section{GROUP II (table 2)}

Seven of the 9 patients had had deep vein thromboses (accompanied by pulmonary emboli in two), while in two the cerebral vessels were affected (transient ischaemic attacks in one patient and cerebrovascular accident in one). In the patients with recurrent deep vein thromboses, despite long term treatment with warfarin, further thrombotic events occurred in all.

Further deep vein thromboses were associated with warfarin withdrawal in five patients. Warfarin was withdrawn for one of the following reasons: (a) it was thought that the antiphospholipid antibody levels in one patient had reverted to negative. After withdrawal, however, it was found that although the anticardiolipin antibody levels were in fact negative, a lupus anticoagulant was nevertheless still demonstrable; $(b)$ as a precaution, because of caesarean section in a pregnant patient; $(c)$ to undertake renal biopsies in two further patients; and $(d)$ bloody diarrhoea in one patient.
The use of subcutaneous heparin (15000 units daily) was ineffective in preventing further deep vein thromboses and pulmonary emboli in two patients. Absorption of heparin subcutaneously may be erratic and the bioavailability reduced. Poor compliance was responsible for inadequate anticoagulation control in one patient and transiently inadequate anticoagulation control (international normalisation ratio $<2$ ) in a further three patients. In one of these, despite being stable with anticoagulation therapy, two episodes of apparent warfarin resistance occurred with an inadequate international normalisation ratio despite doubling the oral warfarin dose. These episodes lasted for three weeks, the patient then reverting to normal control with the previous warfarin dosage. Eight of the nine patients were anticardiolipin antibody positive and remained positive throughout the five years. Four were high positive for IgG anticardiolipin antibodies, one of whom had changed to a moderate positive level at the end of the five years. Two were moderate IgG anticardiolipin antibody positive and two were low positive. Initially low positive IgG anticardiolipin antibodies in one patient had reverted to negative at the end of the period. In this patient moderately increased IgM anticardiolipin antibodies had changed to low levels of the same isotype. One patient with moderately increased IgG anticardiolipin antibodies had an accompanying low level of the IgM isotype.

Table 2 Antiphospholipid syndrome: group $I I^{*}$

\begin{tabular}{|c|c|c|c|c|c|c|c|c|c|c|c|c|c|}
\hline \multirow{2}{*}{$\begin{array}{l}\text { Case } \\
\text { No }\end{array}$} & \multicolumn{2}{|c|}{ Diagnosis } & \multirow{2}{*}{$\begin{array}{l}\text { Initial APS } \\
\text { associated } \\
\text { manifestations }\end{array}$} & \multicolumn{3}{|l|}{ Treatment } & \multirow{2}{*}{$\begin{array}{l}\text { Further } \\
\text { complications }\end{array}$} & \multicolumn{3}{|l|}{ Treatment } & \multicolumn{3}{|c|}{$\begin{array}{l}\text { Antiphospholipid } \\
\text { antibodies }\end{array}$} \\
\hline & Onset & $\begin{array}{l}\text { At } 5 \\
\text { years }\end{array}$ & & Anticoagulation & $\begin{array}{l}\text { Pre } \\
\text { imm }\end{array}$ & $\begin{array}{l}\text { onel } \\
\text { ippression }\end{array}$ & & Anticoagulation & $\begin{array}{l}\text { Pre } \\
\text { imm }\end{array}$ & $\begin{array}{l}\text { nisolonel } \\
\text { inosuppression }\end{array}$ & $I g G$ & $I g M$ & LAt \\
\hline 1 & SLE† & SLE & TIA† & Warfarin & + & Aza† & TIA & $\underset{\text { Warfarinin }}{\text { Wa }}$ & + & Aza & $\mathbf{H}$ & - & + \\
\hline 2 & SLE & SLE & DVTt & $\begin{array}{l}\text { Warfarin } \\
\text { (withdrawn: } \\
\text { renal biopsy) }\end{array}$ & + & - & $\begin{array}{l}\text { DVT (after } \\
\text { warfarin } \\
\text { withdrawal) }\end{array}$ & $\begin{array}{l}\text { Warfarin } \\
\text { reinstituted }\end{array}$ & + & - & $\mathrm{L} \rightarrow \mathrm{N}$ & $M \leftrightarrow L$ & + \\
\hline 3 & LLD† & SLE & $\underset{\text { PE } \dagger}{\text { DVT }}(4)$, & Warfarin & - & - & $\begin{array}{l}\text { Axillary artery } \\
\text { thrombosis } \\
\text { Reocclusion } \\
\text { axillary artery } \\
\text { PE }\end{array}$ & $\begin{array}{l}\text { Short term } \\
\text { intravenous } \\
\text { heparin and } \\
\text { epoprostenol } \\
\text { Phenindione } \\
\text { Phenindione }\end{array}$ & - & - & $\mathbf{M}$ & - & + \\
\hline 4 & LLD & SLE & $\begin{array}{c}\text { DVT, fetal } \\
\text { losses }\end{array}$ & Warfarin & + & Aza & $\mathrm{PE}$ & Phenindione & + & Aza & $\mathrm{H} \rightarrow \mathrm{M}$ & - & + \\
\hline 5 & SLE & SLE & DVT & $\begin{array}{l}\text { Warfarin } \\
\text { (withdrawn: } \\
\text { caesarean } \\
\text { section) }\end{array}$ & + & Aza & DVT & $\begin{array}{l}\text { Warfarin (withdrawn: } \\
\text { renal biopsy), } \\
\text { SC heparin } \\
\text { ( } 5000 \text { U } 8 \text { hourly) } \\
\text { Intravenous heparin } \\
\text { (48 h), warfarin } \\
\text { and aspirin }\end{array}$ & + & $\begin{array}{l}+ \\
\text { (pulse } \\
\text { (cyclophosphamide) }\end{array}$ & $\mathbf{L}$ & - & ND \\
\hline 6 & SLE & SLE & DVT (3) & $\begin{array}{l}\text { Warfarin, } \\
\text { nicoumalone }\end{array}$ & + & Aza & $\begin{array}{l}\begin{array}{c}\text { Axillary vein } \\
\text { thrombosis }\end{array} \\
\text { DVT and PE } \\
\text { Angina/MI† } \\
\text { CVA } \\
\begin{array}{l}\text { Subclavian } \\
\text { vein occlusion }\end{array}\end{array}$ & $\begin{array}{l}\text { Warfarin } \\
\text { (INR } \ddagger \text { low) } \\
\text { Warfarin } \\
\text { (dose omitted) } \\
\text { Warfarin ( } \uparrow \text { dose) } \\
\begin{array}{l}\text { Warfarin }+ \\
\text { aspirin }\end{array}\end{array}$ & + & Aza & - & - & + \\
\hline $\begin{array}{l}7 \\
8\end{array}$ & $\begin{array}{l}\text { LLD } \\
1^{\circ} \mathrm{APS}+\end{array}$ & $\begin{array}{l}\text { LLD } \\
1^{\circ} \mathrm{APS}\end{array}$ & $\begin{array}{l}\text { DVT } \\
\text { DVT (3) }\end{array}$ & $\begin{array}{l}\text { Warfarin } \\
\text { Warfarin }\end{array}$ & + & $\frac{\text { Aza }}{-}$ & $\begin{array}{l}\text { DVT } \\
\text { DVT }\end{array}$ & $\begin{array}{l}\text { Warfarin } \\
\text { Warfarin } \\
\text { (poor control) } \\
\uparrow \text { Warfarin }\end{array}$ & - & - & $\begin{array}{l}\mathbf{H} \\
\mathbf{H}\end{array}$ & - & $\begin{array}{l}+ \\
+\end{array}$ \\
\hline 9 & $1^{\circ}$ APS & LLD & CVAt (2) & $\begin{array}{l}\text { Warfarin } \\
\text { Warfarin }+ \\
\text { aspirin }\end{array}$ & - & - & $\begin{array}{l}\text { CVA } \\
\text { DVT } \\
\text { CVA }\end{array}$ & $\begin{array}{l}\uparrow \text { Warfarin } \\
\text { Warfarin + aspirin } \\
\text { Phenindione, } \\
\text { aspirin }\end{array}$ & + & Aza & $M$ & $\mathbf{L}$ & + \\
\hline
\end{tabular}

*Patients who developed recurrent thrombotic events during the five year follow up.
tSLE = systemic lupus erythematosus; $L L D=$ lupus-like disease; $1^{\circ}$ APS = primary antiphospholipid syndrome; TIA =transient ischaemic attacks; DVT $=$ deep vein $\dagger \mathrm{SLE}=$ systemic lupus erythematosus; $\mathrm{LLD}=$ lupus-like disease; $1^{\circ} \mathrm{APS}=$ primary antiphospholipid syndrome; TIA =transient ischaemic attacks; $\mathrm{DVT}=\mathrm{deep}$ vein
thromboses; $\mathrm{PE}=$ pulmonary embolus; $\mathrm{CVA}=$ cerebrovascular accident, $\mathrm{Aza}=\mathrm{azathioprine} ; \mathrm{MI}=$ myocardial infarction; aCL $=$ anticardiolipin antibodies- $\mathrm{H}=\mathrm{high}$, $M=$ moderate, $\mathrm{L}=$ low, $\mathrm{N}=$ negative; $\mathrm{LA}=$ lupus anticoagulant.

fINR = international normalisation ratio. 


\section{Discussion}

The patients were divided into two groups - with and without thromboembolic complications-to assess whether this arbitrary division might perhaps provide some clues as to the reasons why some patients with antiphospholipid antibodies developed further complications and whether these complications bore any relation to the levels or isotype of anticardiolipin antibody, or to the type of treatment given. It can be seen from the tables that in several patients the initial thrombotic event was related to factors such as oral contraceptive use (in two patients), occurred in the postpartum period in three, at which time (together with late pregnancy) a hypercoagulable state exists. Inadequate treatment with warfarin was responsible for recurrent thromboembolic events in four patients. An international normalisation ratio of less than three is clearly ineffective in this group of patients, and on further investigation it was found that most doctors attending anticoagulation clinics were content with a ratio in the range of 2 to $2 \cdot 5$. It is therefore necessary that attending doctors should be aware of the high risk of thrombosis reoccurring in this group of patients and they should maintain the ratio at a higher therapeutic level than necessary in patients without antiphospholipid antibodies.

Warfarin resistance with a dose four to five times greater than normal ( $20 \mathrm{mg} /$ day) was necessary to achieve normalisation ratios of more than three in two patients. One of these also had a similar resistance to phenindione and more than $100 \mathrm{mg}$ daily was necessary. This phenomenon has been noted in several other patients with antiphospholipid antibodies, who are not included in this study.

Subcutaneous heparin seemed to be ineffective in the prevention of recurrent thromboses in a dosage of 5000 units eight hourly. Warfarin had been withdrawn and SC heparin started as a therapeutic anticoagulation 'cover' in several patients undergoing caesarean section or renal biopsy. Intravenous heparin in a dose of $\mathbf{4 0} 000$ units daily seemed to prevent total occlusion of an axillary artery as well as a threatened myocardial infarction in another patient. One patient had developed a deep vein thrombosis at the onset of acute nephritis in the absence of a nephrotic syndrome. Deep vein thrombosis occurred in another patient in the postpartum period concomitant with a flare of her lupus with renal disease and a nephrotic syndrome.

Patients with a nephrotic syndrome may have a spectrum of haemostatic disorders, particularly thromboembolism. Four major abnormalities may contribute to this hypercoagulable state, including abnormalities in the coagulation cascade, deficiency of specific coagulation inhibitors, such as antithrombin III, protein C, and protein $S$, abnormalities of the fibrinolytic system, or alterations in platelet function, particularly increased platelet adhesion and aggregation. ${ }^{12-18}$

The levels of anticardiolipin antibody in both groups were almost identical, with similar numbers of patients being in the high, medium, and low positive IgG anticardiolipin antibody range. IgM anticardiolipin antibodies were only present in two patients in group I and two in group II.

Anticardiolipin antibody levels changed in only three patients over the five year period, and in these, levels actually fell. There did not seem to be any sudden rise of anticardiolipin antibody levels in the three to six weeks before the recurrent thrombotic events. It is therefore concluded that the actual levels of anticardiolipin antibody as monitored in the low, medium, and high ranges did not influence the development of complications in these patients.

Six patients in group I and six in group II were receiving prednisolone treatment. Only one patient was receiving azathioprine in group I, whereas four in group II were receiving it. Pulse cyclophosphamide had been given to two patients in group II but not to any in group I. Background azathioprine treatment did not seem to prevent recurrent complications, nor did the long term administration of prednisolone. Because only two patients had received pulse cyclophosphamide treatment (for acute renal disease in both) no assessment of the efficacy of this form of treatment in the prevention of thrombotic complications is possible. The use of dipyridamole seemed to be ineffective alone in the prevention of thrombosis. Salicylates (low dose aspirin $75 \mathrm{mg}$ daily) were effective in the prevention of further thrombotic events in three patients in group I (three with previous cerebrovascular accidents—one additionally had two previous deep vein thromboses: during oral contraceptive use and in the postpartum period). The salicylates had been combined with prednisolone in two of these patients and azathioprine as well in the third. Warfarin alone prevented further complications in three patients (two with cerebrovascular accidents, one with peripheral arterial occlusion) in group I. Additional aspirin was required to prevent recurrent transient ischaemic attacks in one patient in group II, however.

There have been few previously published chronological or sequential studies on patients with antiphospholipid antibodies. Elias and Eldor found similar results in their study done in $1984,{ }^{19}$ anticoagulant treatment being effective in the prevention of further vascular occlusions. Out et al recently followed up 53 patients with SLE over a four year period, the mean duration of follow up being 26 months, and compared the anticardiolipin antibody levels with disease activity and treatment with prednisolone. ${ }^{20}$ Forty per cent (for the IgG isotype) and $45 \%$ (for the IgM isotype) of patients remained in the same anticardiolipin antibody category detected at entrance to the study. Marked increases from negative to high positive were not accompanied by any evidence of thrombosis or thrombocytopenia. Fluctuations of levels occurred irrespective of changes in prednisolone dose. Patients receiving low dose prednisolone or none at all also changed their category. In $23 \%$ of patients, increase of IgG anticardiolipin antibodies was significantly associated with thrombosis, whereas during moderate or severe disease activity the correlation was not significant. Association of the IgM anticardiolipin antibody levels with 
thrombotic events was, however, independent of lupus flares and remissions and was significant. These authors suggested that because of the great variability in anticardiolipin antibody concentrations (which is only partially explained by disease activity and prednisolone treatment) at least two samples should be taken for screening purposes-one during low dose prednisolone treatment and one in its absence. The authors also concluded that the IgG anticardiolipin antibody levels were of limited value in identifying patients at risk during exacerbations. The IgM anticardiolipin antibody, however, was thought by them to be more reliable as a predictor of future risks. Other authors have also studied variations of anticardiolipin antibody levels during disease activities. Kalunian et al although finding a positive association between anticardiolipin antibodies and thrombosis, fetal loss, and thrombocytopenia, found no correlation of disease activity with anticardiolipin antibody levels. ${ }^{21}$

Recently, a retrospective study on patients with SLE was performed by Ishii et al. ${ }^{22}$ Eighty patients were classified as having active disease. Sixty nine of $155(45 \%)$ were positive for IgG anticardiolipin antibodies. Serial measurements of IgG anticardiolipin antibodies allowed the patients to be further classified into subgroups: (a) those who were persistently positive for IgG anticardiolipin antibodies, and (b) those who were only positive in the active phases of the disease. The level of IgG anticardiolipin antibodies was significantly higher in group $(a)$ and the incidence of thromboses, spontaneous abortions and lupus anticoagulant positivity was also significantly higher in this group. The incidence of these events was very low in group (b), suggesting that those patients who presented with persistently high levels of IgG anticardiolipin antibodies, irrespective of disease activity and treatment, are at risk for thromboses and spontaneous abortion. From this study it also seemed that IgG anticardiolipin antibodies in group ( $a$ ) patients could not be reduced by treatment with corticosteroids, nor apparently were they reducible by immunosuppressant therapy. In group (b), however, with more active disease and a high incidence of renal disease, anticardiolipin antibodies decreased easily in response to either corticosteroids, immunosuppressants, or both.

Drenkard et al studied six patients with SLE and found that falls of antiphospholipid antibodies occurred within two weeks (average eight days) of a thrombotic episode. ${ }^{23}$ All patients had high titres of IgG anticardiolipin antibodies before the thrombosis. High levels of IgM anticardiolipin antibodies in three patients also fell coincidentally with the thromboocclusive event. A similar occurrence had been previously reported by Sturfelt et al. ${ }^{24}$ Drenkard et al postulated that consumption of antiphospholipid antibody occurred at the time of the thromboses. Treatment was excluded as a variable by these investigators.

Gladman and Urowitz in an earlier study ${ }^{25}$ reviewed the incidence of venous syndromes reported by other authors as well as reporting on 17 of their own patients, who had 21 episodes of venous thromboses or pulmonary embolism, or both. In 16 of the 21 episodes the SLE was considered to be active in 12 patients. Of great interest was the finding that focal glomerulonephritis, mesangial involvement as well as mesangial sclerosis, was present in five patients with nephrotic syndrome and yet all had experienced venous thromboses or pulmonary embolism, or both. The lupus anticoagulant was detected in only three of their patients at the time of the occlusion. Other risk factors in their patients, such as the use of oral contraceptives, excessive smoking, raised cholesterol and triglyceride concentrations, were also assessed. Only one patient had taken oral contraceptives for two years up to the time of the thrombosis. Eight of the 17 smoked and in three increased lipid concentrations were detected. Angles-Cano et al subsequently studied 28 patients with SLE, ${ }^{26}$ five of whom had had thrombotic episodes, which had occurred concurrently with a flare of the disease in four of these five patients. In three, the lupus anticoagulant was present but 12 patients (43\%) had evidence of prolongation of the activated partial thromboplastin time and prolonged prothrombin time in the absence of any thromboembolic complications. Peck et al reported on 14 of 114 patients who had episodes of thrombophlebitis with $\mathrm{SLE}^{27}$ and concluded that the presence of active SLE alone might be sufficient to increase the risk of thrombosis, though other predisposing risk factors might have been operating. Three of their 14 patients were seriously ill and in bed when the occlusions occurred. Nine, however, had no known predisposing factors.

\section{Conclusions}

From this series it seems that there were no broad significant differences in the levels of anticardiolipin antibodies between those patients who developed recurrent thromboembolic events (group II) and those who did not (group I). There was no rise in anticardiolipin antibody titre preceding any thrombotic events and this fact concurs with the findings of Out $e t \mathrm{al}^{20}$ that marked increases from negative to high positive levels were not associated with thrombotic events. These antibodies, nevertheless, still represent excellent markers for patients at risk for vascular occlusions. It should be emphasised, however, that anticardiolipin antibodies were not determined immediately preceding the thrombotic events.

Thrombotic events tended to occur at times of hypercoagulability-for example, in the postpartum period and after the administration of oral contraceptives in several patients in group $I$, and were precipitated by problems in anticoagulation control in the group II patients. Some patients required large doses of anticoagulants, but this apparent insensitivity to anticoagulants was transient. It is suggested that ideally, the international normalisation ratio should be kept above three in patients with antiphospholipid antibodies. Subcutaneous heparin in a dosage of 5000 units eight hourly did not prevent recurrent thromboses in one 
patient at a time of identified risk. The long term use of azathioprine or prednisolone treatment, or both, to control activity of the SLE also did not seem to prevent further thromboembolic events in the group II patients. Patients with recurrent deep vein thromboses did less well than those with cerebrovascular accidents, with problems related to maintaining an adequate normalisation ratio being common. The use of low dose salicylate in some patients with cerebrovascular accidents was effective and its addition to warfarin treatment controlled recurrent transient ischaemic attacks in one patient with valvular disease.

It is also of interest that of the three patients conforming to a 'primary' antiphospholipid syndrome, only one changed category over the five year period of the study to lupus-like disease.

This work was supported by the British SLE Aid Group and the Jean Shanks Foundation. Thanks are due to Mrs Barbara Issom Jean Shanks Foundation.
for typing the manuscript.

1 Boey M L, Colaco C B, Gharavi A E, Elkon K B, Loizou S, Hughes $\mathbf{G}$ R. Thrombosis in systemic lupus erythematosus: Hughes $\mathrm{G}$ R. Thrombosis in systemic lupus erythematosus: striking association with the presence

2 Harris E N, Gharavi A E, Boey M L, et al. Anticardiolipin antibodies: detection by radioimmunoassay and association with thrombosis in systemic lupus erythematosus. Lance 1983; ii: $1211-4$.

3 Derue G J, Englert H J, Harris E N, et al. Fetal loss in systemic lupus: association with anticardiolipin antibodies. f Obstet Gynecol Neonatal Nurs 1985; 5: 207-9.

4 Asherson R A, Harris E N. Anticardiolipin antibodies clinical associations. Postgrad Med f 1987; 62: 1081-7.

5 Tan E M, Cohen A S, Fries J F, et al. The 1982 revised criteria for the classification of systemic lupus erythematosus. Arthritis Rheum 1982; 25: 1271-7.

6 Harris E N, Baguley E, Asherson R A, Hughes G R V. Clinical and serological features of the "antiphospholipid clinical and serological features of the "antiphospholipid

7 Asherson R A, Khamashta M A, Ordi-Ros J, et al. The "primary" antiphospholipid syndrome: major clinical and "primary" antiphospholipid syndrome: major clinical and

8 Mackworth-Young C G, David J, Louizou S, Walport M J. "Primary" antiphospholipid syndrome: features of patients with raised anticardiolipin antibodies and no other disorders. Ann Rheum Dis 1989; 48: 362-7.

9 Alarcon-Segovia D, Sanchez-Guerrero J. Primary antiphospholipid syndrome. 7 Rheumatol $1989 ; 16$; 482-8.

10 Gharavi A E, Harris E N, Asherson R A, Hughes G R V. Anticardiolipin antibodies: isotype distribution and phospholipid specificity. Ann Rheum Dis 1987; 46: 1-6.

11 Exner T. Similar mechanisms of lupus anticoagulants. Thromb Haemost 1985; 53: 15-18.

12 Llach F. Nephrotic syndrome: hypercoagulability, renal vein thrombosis and other thromboembolic complications. In Brenner B M, Stein J H, eds. Nephrotic syndrome. Vol 9. Contemporary issues in nephrology. New York: Churchil Livingstone, 1981: 121-44.

13 Vasiri D, Brenton H E, Ness R. Changes of coagulation factors IX, VIII, VII, $\mathrm{X}$ and $\mathrm{V}$ in nephrotic syndrome. $A m$ I Med Sci 1980; 280: 167-71.

14 Kaufmann R H, Veltkamp J J, Van Tilburg N H, Van Es $\mathrm{L}$ A. Acquired antithrombin III deficiency in thrombosis in the nephrotic syndrome. Am 7 Med 1978; 65: 607-13.

15 Vigano D'Angelo S, D'Angelo A, Kaufmann C, et al. Protein $S$ deficiency occurs in the nephrotic syndrome. Ann Inter Med 1987; 107: 42-7.

16 Morrison B W. Protein S and the nephrotic syndrome. Ann Intern Med 1988; 108: 152 .

17 Thomson C, Forbes C D, Prentice C R, Kennedy A C Changes in blood coagulation and fibrinolysis in nephrotic syndrome. Am ₹ Med 1974; 43: 399-407.

$18 \mathrm{Kuhlmann}$ U, Steurer J, Siegenthaler W. Platelet aggregation and B-thromboglobulin levels in nephrotic patients with and without thrombosis. Clin Nephrol 1981; 15: 229-35.

19 Elias M, Eldor A. Thromboembolism in patients with the "lupus" type circulating anticoagulant. Arch Intern Med 1984; 144: 510-5.

20 Out I H, De Groot P G, Hasselaar P, van Vliet M, Derksen R H W M. Fluctuations of anticardiolipin antibody levels in patients with systemic lupus erythematosus: a prospecin patients with systemic lupus erythematosus:
tive study. Ann Rheum Dis 1989; 48: 1023-8.

21 Kalunian K C, Peter J B, Middlekauff H R, et al. Clinica significance of a single test for anticardiolipin antibodies in patients with systemic lupus erythematosus. $\mathrm{Am} \mathrm{J} \mathrm{Med}$ 1988; 85: 602-8.

22 Ishii Y, Nagasawa K, Mayumi T, Niho Y. Clinical importance of persistence of anticardiolipin antibodies in systemic lupus erythematosus. Ann Rheum Dis 1990; 49: 387-90.

23 Drenkard C, Sanchez-Guerrero J, Alarcon-Segovia D. Fall in antiphospholipid antibody and time of thrombo occlusive A 1989; 16: 614-7.

24 Sturfelt G, Nived O, Norberg R, Thorstensson R, Krook K. Anticardiolipin antibodies in patients with systemic lupus Anticardiolipin antibodies in patients with system

25 Gladman D D, Urowitz M B. Venous syndromes and pulmonary emoblism in systemic lupus erythematosus. $A n n$ Rheum Dis 1980; 39: 340-3.

26 Angles-Cano E, Sultan Y, Clauvel J P. Predisposing factors to thrombosis in systemic lupus erythematosus. Possible relation to endothelial cell damage. $\mathcal{F}$ Lab Clin Med 1979; 94: 312-23.

27 Peck B, Hoffman G S, Frank W A. Thrombophlebitis in systemic lupus erythematosus. FAMA 1978; 240: 1728-30. 